Historic, Archive Document

Do not assume content reflects current scientific knowledge, policies, or practices. 

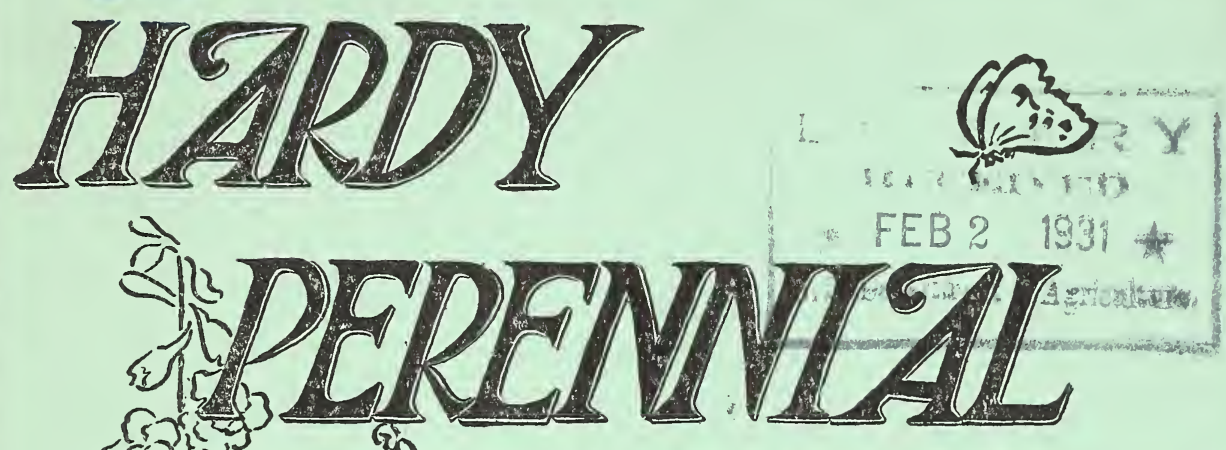

(5)

astis

किती

(iv)

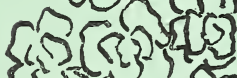

sint

हाin

急

ous 50 .

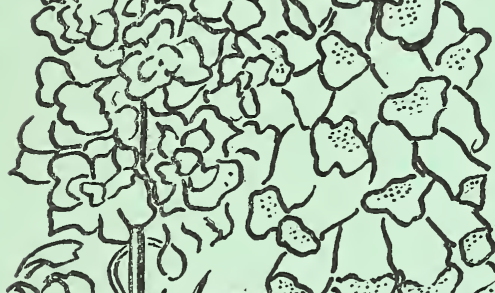

$\pi 0$ (

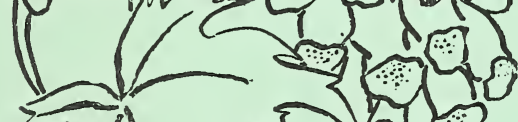

$\sum_{1}$
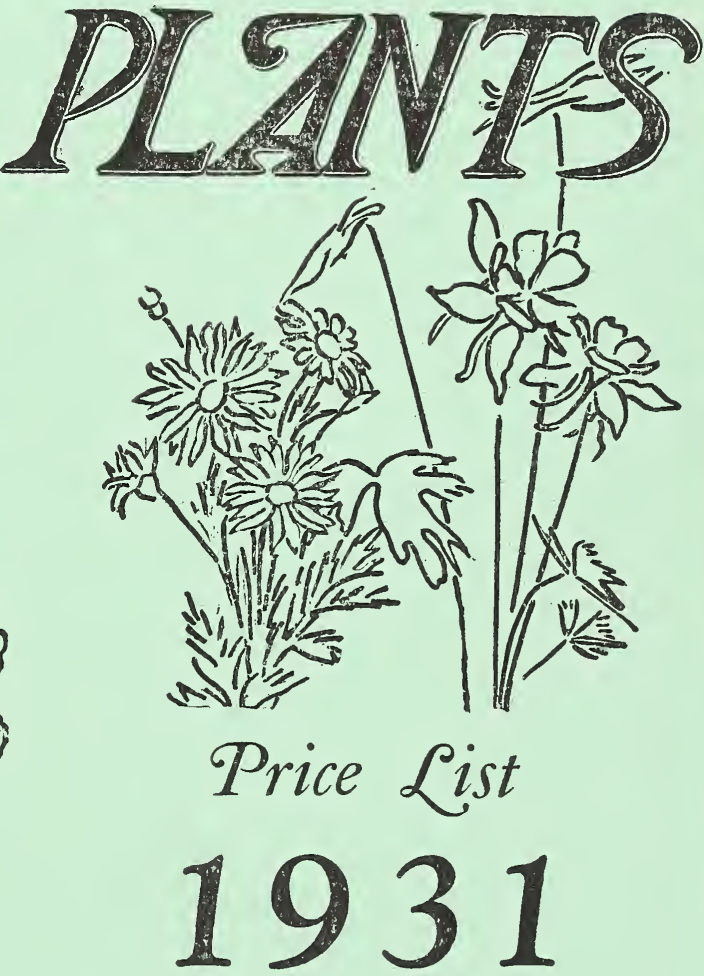

$G \mathbb{R E N} \mathbb{B R O O K}$ GARDENS A M Y HOR E

P. O. Scotch Plains, New Jersey

R. R. Station, Berkeley Heights, New Jersey

Telephone FANwood 2-7519-R-2 


\section{HARDY PERENNIAL PLANTS}

\section{QUALITY}

My plants are field grown; that is, they are grown out of doors from start to finish. They have been in the ground all winter; consequently there is no question as to their hardiness, and they may be planted out as soon as the ground is dry enough, the earlier the better; late frosts will not harm them at all.

Having been grown from the best strains obtainable from European and American plantsmen, my plants are unsurpassed in quality.

All plants sent out are of blooming size.

\section{PLANTING DIRECTIONS}

Description as to height, color and time of blooming, suitable soil and aspect, and other information necessary for proper planting, is attached to all plants. If further information is desired, I am always glad to answer any questions.

\section{SHIPMENT}

Unless directed otherwise, plants will ordinarily be sent by express, the customer paying the carriage charges. If desired by parcel post, ten per cent should be added to the remittance. Any balance will be refunded.

\section{TERMS}

This price list cancels all previous quotations.

New customers will kindly send remittance with order. If credit is desired, please send references and allow me time to hear from them.

AMY HORE, Green Brook Gardens, Scotch Plains, N. J. 


\section{ANCHUSA MYOSOTIDIFLORA (Siberian Bugloss)}

Aside from the botanical classification this plant has no resemblance whatever to Anchusa Italica. It lacks the coarseness of foliage of the tall anchusas, and is preeminently a plant for the rock garden. It is very hardy and easy to grow and needs no special treatment except that it seems to do rather better in shade than in sun.

Very early in spring the sprays of true forgetmenot flowers appear with the foliage. The flowers last for about six weeks, and before they are past the leaves have expanded to their full size. The latter are very large, dark green and heart shaped. Growing to a height of about one foot, they spread out in a splendid clump that remains in good condition and an ornament to the garden all summer.

Clumps should not be disturbed for several years as they increase in beauty yearly. They are multiplied by division, preferably after blooming in order that they may become established before winter.

Field Grown Clumps............\$5.00 per dozen $\$ 35.00$ per 100

\section{AQUILEGIA (Columbine)}

Although the Columbines are among the best known perennials, they are still among the most popular, for few flowers can equal them in beauty. Their dancing blossoms seem to personify the joyousness and grace and brightness of the young summer, and no spring garden is complete without them.

The plants offered below are two year old field grown clumps that will give quantities of bloom this season. They are a very fine strain, large flowered and long spurred. They are offered in separate colors.

\section{SUTTON'S LONG-SPURRED PINK. \\ SUTTON S LONG-SPURRED BLUE. \\ SUTTON'S LONG-SPURRED PURE WHITE.}

SUTTON'S ALPINA, the true species from the Alps of Switzerland.

Price. $\$ 4.00$ per dozen

$\$ 30.00$ per 100

For other varieties of Aquilegia, see General List.

\section{DIGITALIS, LUTZ HYBRIDS}

An unusually beautiful Foxglove. The spikes are long, the flowers large, and the color ranges from flesh pink to salmon pink and rose.

Foxgloves should be planted as early as the ground can be worked so that they may become established before blooming time in Junle. To be at their best they should have rich, heavy ground and some shade.

Price.

$\$ 3.50$ per dozen

$\$ 25.00$ per 100

\section{DORONICUM CLUSII (Leopard's Bane)}

One of the first flowers to bloom in the spring. The masses of golden flowers and the shining, bright green leaves are doubly welcome because they appear so early. The flowers are valuable for cutting and the foliage remains in good condition all summer. It is very easily increased by division after flowering.

Price $\$ 5.00$ per dozen 


\section{Plants of Outstanding Merit \\ (Continued)}

\section{INCARVILLEA DELAVAYII (Hardy Gloxinia)}

A very beautiful plant which makes a striking display in June, its blooming season. It forms a clump of handsome, pinnate leaves, each one fully a foot in length, and throws up two-foot stems bearing large, trumpet shape, rose colored flowers. It should have a sunny, sheltered situation. The ground should be prepared at least eighteen inches deep with mellow, rich soil, and the roots planted with the crown two inches below the surface. They are well worth any extra trouble taken in planting. I have found them perfectly hardy, but they ought to have two inches of peat moss, or similar covering, on them during the first winter.

Price

$\$ 5.00$ per dozen

$\$ 35.00$ per 100

\section{TROLLIUS LEDEBOURI (Globe Flower)}

The Globe flowers are quite gorgeous with their rich gold flowers. T. Ledebouri is distinguished from the rest of the family by flowering in June instead of early spring, and by its tall stature. It bears its large, open flowers of glowing orange on long stems, and is splendid for cutting Heavy soil and some shade suit it, but it will stand the sun as long as it has plenty of moisture. It is increased by division after flowering.

Price.

$\$ 5.00$ per dozen

$\$ 35.00$ per 100

\section{SWEET WILLIAM (Dianthus Barbatus)}

Those who know only the old time Sweet William will be surprised and delighted with the varieties given below, which are the newest and highest development of this old favorite.

Retaining the abundance of bloom which made Sweet William the most popular flower of old gardens, the size of the flowers has been increased tremendously, and the colors transformed into beautiful clear, harmonious tones. They will be found to come entirely true to the color description.

SUTTON'S PINK BEAUTY. A lovely salmon pink.

SUTTON'S SCARLET. A remarkable color; an intense scarlet.

SUTTON'S FAIRY. A recent introduction with delicate salmon pink flowers, of a much lighter shade than Pink Beauty.

Price $\$ 3.00$ per dozen

$\$ 20.00$ per 100

\section{VIOLA (Tufted Pansy)}

Is there anything that will make a greater return to a gardener for the time and trouble expended than the violas? The first flower to bloom in the spring, the last in the autumn, almost every month in the year you can find their blossoms, and what a glorious burst of color they make in spring and early summer. Nothing stops them except the extreme hot weather of July and August, and with the cool days of September, out they come again to make the garden gay until the freeze up.

They are the easiest of plants to manage. Transplanting does not bother them a bit; they go right on blooming. The only thing they require is moisture. In dry weather the flowers become smaller and smaller, and if the drought continues, they will stop blooming, but even then they will carry on again as soon as they are given water. As they are such prodigal bloomers, they need rich soil, and they must not be allowed to go to seed. If these few requirements are met, they will give such a wealth of flowers of lovely colors as is not equalled by any other plant. 


\section{Plants of Outstanding Merit \\ (Continued)}

VIOLA ODORATA "ROSINA". The new American grown garden violet. Hardy, pink, and very fragrant. For full description see attached slip.

$$
\text { Price.......................\$5.00 per dozen } \$ 35.00 \text { per } 100
$$

VIOLA "JERSEY GEM". No viola has yet appeared to surpass this in value to American gardens. It will stand hot summers and drought as will no other member of the family. The rich violet flowers bloom profusely all summer.

It is very easy to propagate. Simply lift the old clumps and divide into a number of pieces, each of which will quickly grow into a blooming plant. It is wise to divide every year as young plants are more vigorous and will bloom more freely than old clumps.

$$
\text { Price.......................\$3.00 per dozen } \$ 20.00 \text { per } 100
$$

VIOLA "SUTTON'S APRICOT". Very large, circular flowers of a lovely rich apricot, deepening into brilliant orange in the centre. The only viola in existence of this distinctive color. I have found that the best way to manage this viola is, at the end of the season, to spread out the long stems and peg each one down to the ground with a hairpin. New growths will spring up from the centre which will be the blooming stems the following spring. In this way each plant will cover a square foot of space.

$$
\text { Price.....................\$3.50 per dozen } \$ 25.00 \text { per } 100
$$

\section{GENERAL PRICE LIST}

Prices: Unless otherwise noted, $\$ 3.00$ per dozen; $\$ 20.00$ per 100 .

Not less than six plants of one variety are sold at the dozen rate; not less than fifty plants of one variety are sold at the 100 rate.

\section{ACONITUM (Monkshood)}

Autumnale. Dark blue. $2-4$ feet......\$3.50 per dozen

$\$ 25.00$ per 100

Wilsoni. Lavender blue. $7-9$ feet...\$7.50 per dozen

$\$ 60.00$ per 100

\section{ANCHUSA (Bugloss)}

Italica, Lissadell variety $\$ 3.50$ per dozen

$\$ 25.00$ per 100

Myosotidiflora. See page 2 $\$ 5.00$ per dozen

ANTHEMIS TINCTORIA KELWAYII. (Camomile). Golden daisies in June. Good for cutting.

\section{AQUILEGIA (Columbine)}

Chrysantha. A soft yellow. Remains in bloom for a long time.

Haylodgensis Hybrids. From the Royal Moorheim Nurseries of Dedemsvaart, Holland. $\$ 3.50$ per dozen

$\$ 25.00$ per 100

Mrs. Scott Elliott's long-spurred Hybrids.

Sutton's long-spurred Hybrids. See page 2. 
ASTER. Dwarf Species.

Alpinus. Large, single, lavender flowers in May. Fine rock plant. Sub-coeruleus. Similar to Alpinus, but lighter in color.

ASTER (Michaelmas Daisy) Novae Angliae "Barr's Pink." The best pink of the tall fall asters. $\$ 3.50$ per dozen $\$ 25.00$ per 100

\section{ASTILBE (Spirea)}

America. Light pink $\$ 5.00$ per dozen $\$ 35.00$ per 100

Gloria. Late flowering; deep pink...... $\$ 5.00$ per dozen $\$ 35.00$ per 100

Gladstone. Pure white; early. $\$ 5.00$ per dozen $\$ 35.00$ per 100

Queen Alexandra. June flowering; pink $\$ 5.00$ per dozen $\$ 35.00$ per 100

ASPHODELINE LUTEA (Jacob's Rod) ...\$3.50 per dozen

$\$ 25.00$ per 100

BOLTONIA ASTEROIDES. White, aster-like flowers in September.

CAMPANULA PERSICIFOLIA (Peach Leaved Bellflower). A very fine strain of this great border plant. Its outstanding characteristic is the clear, pure color and delicate texture of the large open bells, flowering in June on three foot stalks. A beautiful companion for Delphinium. Blue and white separately.

CHRYSANTHEMUM MAXIMUM (Shasta Daisy). "Mayfield Giant." Enormous flowers on long stems.

CHRYSANTHEMUM “Japanese Mountain". A fine variety of hardy garden chrysanthemums, making shapely bushes two to three feet high covered with quantities of single flowers. In separate colors, yellow and pink.

\section{DELPHINIUM}

Belladonna "Cliveden Beauty".........\$3.00 per dozen

Chinensis "Blue Butterfly" $\$ 2.50$ per dozen

DIANTHUS (Hardy Pink). All the pinks are splendid rock plants.

Arenarius. Sand Pink. Fragrant, fringed white flowers in July. Needs dry soil and sun.

Barbatus. See Sweet William.

Deltoides. Maiden Pink. A pretty creeper with small rosy flowers.

Plumarius. Grass Pink. Gray, glaucus foliage; rose red single flowers with strong clove fragrance.

Speciosus. A delightful pink for the sunny side of the rock garden Rosy, lavender flowers with petals deeply fringed and a most delicious perfume.

DICENTRA SPECTABILIS (Bleeding Heart) $\$ 7.50$ per dozen

DIGITALIS (Foxglove)

Lutz Hybrids. See page 2.

Sutton's Giant Primrose. A deep cream color. 


\section{A NRW VTOLET \\ HARDY - FRAGRANT - PINK \\ VIOLA ODORA'TA \\ "ROSINA"}

This lovely little violet was originated by Mr. Thomas W. Weston, the introducer of Jersey Gen Viola. It has been under observation by Mr. Weston for several years and after thoroughly testing it he has allowed it to be distributed.

"Rosina" is a most delightful introduction and has an assured future in American gardens. As hardy as the wild violet of our woods, it has a fragrance as strong and as delicious as any hot house violet. The color is a soft, yet bright, pink. Quantities of the appealing little flowers appear in spring and again in autumn, and when they are in bloom the air around them is perfumed with their sweetness. It is this sweet scent that will make Rosina beloved in every garden.

It is a very strong grower and can be divided repeatedly. It will stand sun but seems to do rather better when shaded from the hot sun of midsummer.

It will be used in many situations. As an edging to a shady border it is ideal; it is at home in the rock garden; and no doubt it will be naturalized in many a woodland.

$$
\begin{aligned}
& \$ 5.00 \text { per dozen } \\
& \$ 35.00 \text { per } 100
\end{aligned}
$$

\section{A MY IORE}

GROWER OF HATDY PERENNIALS

\section{GREEN BROOK GARDENS}

SCotch Plans, New JuRsey

TEL. FANWOOD 2-7519-R-2 


\section{GENERAL PRICE LIST}

Prices: Unless otherwise noted, $\$ 3.00$ per dozen; $\$ 20.00$ per 100 .

DORONICUM CLUSII. See page 2.

EUPATORIUM COELESTINUM (Hardy Ageratum)

GAILLARDIA (Blanket Flower). "The Dazzler." Showy, very large flowers, copper red with yellow border. Very effective as cut flowers, and one of the few perennials that bloom continuously all summer.

GAURA LINDHEIMERI. Slender, graceful stalks of white flowers with rosy buds. Very pretty for cutting.

HELENIUM AUTUMNALE SUPERBUM (Sneezewort). HOLLYHOCK (Althea Rosea).

Double Salmon Rose.

Double Yellow.

HYACINTHUS CANDICANS (Galtonia-Summer Hyacinth)

$\$ 2.50$ per dozen

$\$ 18.00$ per 100

LINUM PERENNE (Flax). Lovely blue flowers all summer.

LYCHNIS ARKWRIGHTII.

MYOSOTIS ALPESTRIS (Forgetmenot). Sutton's Royal Blue. A beautiful strain of this lovely spring favorite. There is nothing to surpass its rich, bright blue.

NEPETA MUSSINI. A lovely trailer for the rock garden. Velvety gray foliage and charming lavender flowers, which appear from time to time all summer.

\section{OENOTHERA (Evening Primrose)}

Fraseri. Handsome bushes, two feet high, with quantities of golden yellow flowers opening in the day time. A fine flower for cutting.

Macrocarpa. A trailer, bearing enormous solitary golden flowers.

PENTSTEMON (Beard Tongue). Barbatus Torreyi. A hardy and easily grown plant, which throws up tall, slender spikes of coral red flowers in July. Ornamental in the garden and particularly graceful as a cut flower.

PHLOX PANICULATA. The great standby of the garden in midsummer, providing the most brilliant display of color.

Enchantress. A soft, salmon pink with very large trusses. Similar to the well known Elizabeth Campbell but a stronger grower.

$\$ 3.50$ per dozen $\$ 25.00$ per 100

Milly von Hoboken. Clear, bright pink. Enormous individual flowers and large trusses. A very fine phlox.

$\$ 3.50$ per dozen $\quad \$ 25.00$ per 100

Mrs. Jenkins. An old variety, but still the best white.

Thor. An intense, glowing, deep salmon pink. The color has a "carrying" quality that is quite remarkable.

$\$ \mathbf{\$ 3} .50$ per dozen $\quad \$ 25.00$ per 100

W. C. Egan. A pale pink that is very attractive. A good phlox for situations where the more brilliant colors are not desired.

PHLOX SUFFRUTICOSA (Miss Lingard). The best early flowering white. It comes into bloom a month earlier than the paniculata types, and continues in bloom all summer. It is distinguished by shining, dark green foliage which is not attacked by insects nor disease. 


\section{GENERAL PRICE LIST}

Prices: Unless otherwise noted, $\$ 3.00$ per dozen; $\$ 20.00$ per 100 .

\section{PHYSOSTEGIA VIRGINICA (False Dragonhead).}

PLATYCODON GRANDIFLORUM MARIESII (Balloon Flower). An extremely hardy plant which is valuable for the rock garden. It blooms from July until frost, bearing very large blue or white bell flowers. Blue. White.

POLEMONIUM COERULEUM (Jacob's Ladder). Very attractive bright green foliage with blue flowers on eighteen inch stems in May.

POTENTILLA (Cinquefoil). An ornamental plant for either the border or the rock garden. Strawberry-leaved foliage, and small, brilliant red flowers over a long period. Very hardy and easy to grow.

$\$ 3.50$ per dozen $\$ 25.00$ per 100

PRIMULA VERIS (English Cowslip). A plant beloved of English poets for many generations. It is perfectly hardy in our climate if it has plenty of moisture. It ought to be divided every other year immediately after flowering. Its clumps of bright green leaves and brilliant flowers delight us early in spring.

PYRETHRUM ROSEUM (Painted Daisy). Rose colored daisies, two to three inches across, in May and June.

SALVIA (Meadow Sage). Tenorii. Spikes of violet flowers in June, making a mass of color that is very fine. Two feet high.

\section{SCABIOSA (Pincushion Flower)}

Caucasica. Large flowers of a lovely soft shade of lavender, appearing continuously all summer. $\$ 3.50$ per dozen $\$ 25.00$ per 100

Japonica. Handsome, finely cut foliage, with masses of lavender flowers late in summer. Although this plant is classed as a perennial, as a rule it does not live after fiowering and must be increased by seeds.

SIDALCEA (Greek Mallow). A valuable plant for the July garden. Unusually pretty foliage and four foot stalks of clear pink flowers.

$\$ 3.50$ per dozen $\$ 25.00$ per 100

SPIREA. See Astilbe.

STOKESIA (Cornflower Aster).

SWEET WILLIAM. See page 3.

THALICTRUM ADIANTIFOLIUM (Maidenhair Meadow Rue).

TROLLIUS (Globe Flower). See page 3.

VEREASCUM (Mullein). Harkness hybrids. Biennials. These are splendid tall plants, flowering from July through the summe:. I heir spikes of golden blossoms grow to a height of seven feet and more, and are most. decorative. $\$ 3.50$ per dozen

$\$ 25.00$ per 100

VERONICA (Speedwell). There is no more beautiful blue in the garden than the flowers of the Veronicas, while the foliage remains in good coudition and makes a fine mass of green until long after frost. Their long lasting quality makes the fowers excellent for cutting. Spicata. Spikes of fine blue two to three feet high. If the flowers are not allowed to seed, new spikes will appear all summer.

Amethystine. Long trailing stems with soft blue flowers in June.

VIOLA. See page 3 . 